\title{
Maternal protein restriction depresses the duodenal expression of iron transporters and serum iron level in male weaning piglets
}

\author{
Wenqiang $\mathrm{Ma}^{1}$, Jingyu Lu ${ }^{1,2}$, Shuxia Jiang ${ }^{1}$, Demin Cai ${ }^{1}$, Shifeng Pan $^{1}$, Yimin $\mathrm{Jia}^{1}$ and Ruqian Zhao ${ }^{1 *}$ \\ ${ }^{1}$ Key Laboratory of Animal Physiology and Biochemistry, College of Veterinary Medicine, Nanjing Agricultural University, \\ Nanjing 210095, People's Republic of China \\ ${ }^{2}$ School of Food Science and Technology, Jiangnan University, Wuxi 214122, People's Republic of China
}

(Submitted 8 July 2016 - Final revision received 23 February 2017 - Accepted 2 March 2017)

\section{Abstract}

To investigate the effects of maternal dietary protein restriction on offspring Fe metabolism, twenty-four second-parity Landrace $\times$ Yorkshire sows were randomly allocated to standard-protein (SP) and low-protein (LP) groups. The SP sows were fed diets containing 15 and $18 \%$ crude protein throughout pregnancy and lactation, respectively, whereas the LP sows were subjected to $50 \%$ dietary protein restriction. Offspring birth weight was not affected, but the body weight at weaning $(P=0 \cdot 06)$ and average daily gain $(P=0 \cdot 01)$ of the female piglets were significantly decreased. Serum Fe level in the LP piglets was markedly decreased at weaning, especially in males $(P=0 \cdot 03)$. Serum ferritin level $(P=0.08)$ tended to be lower, yet serum transferrin was greatly higher $(P=0 \cdot 01)$ in male weaning piglets of the LP group. Duodenal expression of the divalent metal transporter 1 (DMT1) and ferroportin (FPN) was surprisingly reduced $(P<0 \cdot 05)$ at the level of protein, but not at the mRNA level, in male weaning piglets of the LP group. Male weaning piglets born to the LP sows exhibited higher hepatic hepcidin levels $(P=0 \cdot 09)$, lower hepatic expression of transferrin $(P<0 \cdot 01)$ and transferrin receptor $1(P<0 \cdot 05)$ at the level of mRNA. However, no significant differences were observed for hepatic Fe storage, ferritin, transferrin and transferrin receptor 1 protein expression in male weaning piglets of the two groups. These results indicate that maternal protein restriction during pregnancy and lactation influences growth of female offspring at weaning, reduces duodenal expression of Fe transporters (DMT1 and FPN) and decreases serum Fe level in male weaning piglets.

\section{Key words: Maternal protein restriction: Iron transporters: Serum iron: Weaning piglets}

Fe deficiency is a common nutritional problem for piglets raised indoors during the growing period. Fe deficiency reduces the rate of $\mathrm{Hb}$ formation and erythrocyte count, and furthermore, it results in pale mucous membranes, enlarged heart, skin oedema, listlessness and spastic breathing (thumps) in suckling piglets $^{(1)}$. Confinement-reared suckling piglets are given access to Fe from two main sources: sows' milk and exogenous Fe supplementation $^{(2)}$. Sows' milk could not satisfy the daily requirements of $\mathrm{Fe}$ for the sucking piglets. It is also a routine practice to administer an intramuscular injection of an organic Fe complex such as iron dextran within the 1st week of life for neonatal piglets ${ }^{(3)}$.

Fe absorption mainly occurs in the duodenum, where Fe is taken up by enterocytes via the divalent metal transporter 1 (DMT1) pathway in mammals ${ }^{(4,5)}$. Once inside the enterocytes, Fe can be stored as ferritin and exported by ferroportin $(\mathrm{FPN})^{(6,7)}$ into the systemic circulation via the basolateral membrane. Systemic Fe homoeostasis is mediated by hepcidin, which is exclusively synthesised by the liver and targets the $\mathrm{DMT}^{(8)}$ and $\mathrm{FPN}^{(9)}$ of enterocytes to reduce intestinal $\mathrm{Fe}$ transport. The intestinal Fe transport could be influenced by several dietary factors including amino acids, vitamins, plant components and so on ${ }^{(10-12)}$.

It has been noted that dietary protein affects Fe absorption and metabolism in a dose-dependent manner ${ }^{(13-15)}$. Previous research demonstrates that a diet composed of 15-18\% protein is necessary for adequate Fe absorption in rats ${ }^{(15,16)}$. The proteinfree or low-protein (LP) diet significantly decreases Fe absorption in rats ${ }^{(13,15)}$. Klavins et al. $^{(13)}$ reported that Fe absorption was impaired in rats fed a protein-free diet compared with those provided a diet containing $10 \%$ casein. A 5 or $10 \%$ protein diet given over 4 weeks leads to lower liver Fe concentrations in rats compared with rats fed $18 \%$ dietary protein, whereas there is no difference in hepatic Fe storage in rats provided diets containing 15,18 or $25 \%$ protein $^{(13)}$. Besides, the colostrum, milk and serum Fe levels do not differ when sows are fed diets containing 12 or $16 \%$ protein during $1-21 \mathrm{~d}_{\text {postpartum }}^{(14)}$.

Numerous studies indicate that maternal LP diet during gestation and/or lactation leads to altered carbohydrate metabolism, glucose metabolism or metabolic disorders in offspring ${ }^{(17,18)}$.

Abbreviations: DMT1, divalent metal transporter 1; FPN, ferroportin; LP, low protein; SP, standard protein; TF, transferrin.

* Corresponding author: R. Zhao, email zhao.ruqian@gmail.com 
In addition, maternal LP diet ( $5 \%$ protein) could suppress the Fe absorption in rats at weaning compared with those of female rats fed a high-protein diet (18\% protein) throughout pregnancy and lactation $^{(19)}$. Fe is an essential trace element and is important for cell functions at biological, chemical and molecular levels ${ }^{(2)}$. To date, a limited number of studies have focused on offspring Fe metabolism exposed to maternal protein restriction. Therefore, the present study, using a pig model, was aimed, first, to assess the influence of maternal protein restriction on offspring $\mathrm{Fe}$ metabolism at birth and weaning and, second, to analyse the possible mechanisms underlying such an effect.

\section{Methods}

\section{Animals and samples}

The animal experiment was carried out in the Shanghai Haifeng farm in Yancheng City, Jiangsu Province, People's Republic of China. At 1 week after artificial insemination, twenty-four secondparity cross-bred sows (Landrace $\times$ Yorkshire) were randomly allocated to standard-protein (SP) and LP groups. All sows were housed in individual gestation stalls $(2.1 \times 0.60 \times 0.97 \mathrm{~m})$ with half-slatted concrete floors, individual feeders and drinkers made of stainless steel. Sows were transferred to the farrowing pens $(2.1 \times 3.0 \mathrm{~m}$, stainless steel stall and plastic floor $) 1$ week before the predicted farrowing date. The warm-air blower, wetted-pad and air-exhaust fan were used to maintain room temperature $\left(17-25^{\circ} \mathrm{C}\right)$ and humidity $(70-80 \%)$ during gestation and lactation. Sows in the SP group were fed diets containing 15 and $18 \%$ crude protein, whereas those in the LP group were fed diets containing 7.5 and $9 \%$ crude protein during gestation and lactation, respectively (Table 1). During the early, middle and late gestation periods, sows were fed three times (at 05.00, 10.00 and 17.00 hours)/d and given a ration of $1.2,1.8$ and $2.4 \mathrm{~kg} / \mathrm{d}$, respectively.

Table 1. Composition and nutrient content of the experimental diets

\begin{tabular}{|c|c|c|c|c|}
\hline \multirow[b]{2}{*}{ Items } & \multicolumn{2}{|c|}{ Gestation period } & \multicolumn{2}{|c|}{ Lactation period } \\
\hline & SP & LP & SP & LP \\
\hline \multicolumn{5}{|l|}{ Ingredient (g/kg) } \\
\hline Maize & 370 & 615 & 332.5 & 547 \\
\hline Wheat & 300 & 100 & 100 & 100 \\
\hline Wheat bran & 80 & 100 & 50 & 50 \\
\hline Soyabean meal & 170 & 0 & 253 & 30 \\
\hline Maize starch & 0 & 100 & 150 & 150 \\
\hline Lignocelluloses & 30 & 40 & 0 & 15 \\
\hline $\mathrm{CaHPO}_{4}$ & 20 & 25 & 20 & 30 \\
\hline Soyabean oil & 10 & 0 & 34.5 & 38 \\
\hline Fishmeal & 0 & 0 & 40 & 20 \\
\hline Premix ${ }^{*}$ & 20 & 20 & 20 & 20 \\
\hline \multicolumn{5}{|l|}{ Calculated composition (\%) } \\
\hline Digestible energy (MJ/kg) & $13 \cdot 1$ & $13 \cdot 1$ & 14.4 & 14.4 \\
\hline Crude protein (\%) & $15 \cdot 0$ & 7.5 & $18 \cdot 0$ & 9.0 \\
\hline $\mathrm{Ca}(\%)$ & 0.8 & 0.9 & 0.9 & 0.9 \\
\hline $\mathrm{P}(\%)$ & 0.7 & 0.6 & 0.7 & 0.7 \\
\hline $\mathrm{Fe}(\mu \mathrm{g} / \mathrm{g}) \dagger$ & 211 & 197 & 262 & 238 \\
\hline
\end{tabular}

SP, standard-protein; LP, low-protein

* All additives added in the complete diet (per $100 \mathrm{~kg}$ ): retinol, $0.66 \mathrm{~g}$ cholecalciferol, $17.5 \mathrm{mg}$ vitamin $\mathrm{K}_{3}, 0.8 \mathrm{~g}$; vitamin $\mathrm{B}_{1}, 0.8 \mathrm{~g}$; vitamin $\mathrm{B}_{2}, 3280 \mathrm{mg}$; vitamin $\mathrm{B}_{6}, 1.30 \mathrm{~g}$ vitamin $B_{12}, 8.8 \mathrm{mg}$; lysine, $144 \mathrm{~g}$; niacin, $9.0 \mathrm{~g}$; pantothenic acid, $5.0 \mathrm{~g}$ D-pantothenic acid, $4.0 \mathrm{~g}$; folic acid, $10.4 \mathrm{~g}$; biotin, $60 \mathrm{mg}$; D-biotin, $32 \mathrm{mg}$; choline chloride, $60 \mathrm{~g}$; vitamin C, $40 \mathrm{~g}$; $\mathrm{Mn}$ (as $\mathrm{MnSO}_{4} \cdot \mathrm{H}_{2} \mathrm{O}$ ), $1.6 \mathrm{~g}$; $\mathrm{Zn}$ (as $\mathrm{ZnSO}_{4} .7 \mathrm{H}_{2} \mathrm{O}$ ), $14 \mathrm{~g}$; ferrous iron (as $\mathrm{FeSO}_{4} .7 \mathrm{H}_{2} \mathrm{O}$ ), $14 \mathrm{~g}$; $\mathrm{Cu}$ (as $\mathrm{CuSO}_{4} .5 \mathrm{H}_{2} \mathrm{O}$ ), $4.0 \mathrm{~g}$; $\mathrm{Se}$ (as $\mathrm{NaSe}_{2} \mathrm{O}_{3}$ ), $40 \mathrm{mg}$; sodium chloride, $6.0 \mathrm{~g} ; \beta$-xylanase, $16000 \mathrm{kIU}$.

† Actual measured level.
Sows were fed the lactation diet twice daily (05.00 and 17.00 hours) at $4.2 \mathrm{~kg} / \mathrm{d}$ during lactation. Sows were provided ad libitum access to tap water (containing $\mathrm{Fe}$ at $2.5 \mathrm{mg} / \mathrm{l}$ ) throughout pregnancy and lactation. Newborn piglets were allowed free access to their mothers until weaning. Piglets were given $100 \mathrm{mg}$ of supplementary Fe (iron dextran) by intramuscular injection at $3 \mathrm{~d}$ of age.

Piglets were individually weighed immediately after parturition and at weaning on day 28 without fasting. Maternal blood samples were collected from the jugular vein at day 10 after parturition. One male and one female piglet per litter were euthanised for sampling at birth and weaning, respectively. Blood samples were centrifuged at $4^{\circ} \mathrm{C}$ at $1000 \boldsymbol{g}$ for $10 \mathrm{~min}$, and serum was subsequently collected and stored at $-20^{\circ} \mathrm{C}$ until analysis. The duodenal mucosa and liver samples were collected within 20 min postmortem, snap-frozen in liquid $\mathrm{N}_{2}$ and stored at $-80^{\circ} \mathrm{C}$ until further analysis. The experimental protocol was subject to approval by the Animal Ethics Committee of Nanjing Agricultural University, with the project no. 2012CB124703. Slaughter and sampling procedures complied with the 'Guidelines on Ethical Treatment of Experimental Animals' (2006) no. 398 set by the Ministry of Science and Technology, China.

\section{Determination of serum, liver and tap water iron concentrations}

Serum Fe level was measured using the 7020 Automatic Biochemical Analyzer (Hitachi High-Technologies Corp.) with reagents provided by Nanjing Jiancheng Bioengineering Institute, Nanjing, China. Serum ferritin concentration was determined with a commercial RIA kit (Beijing North Institute of Biological Technology). Serum transferrin (TF) level was measured with an ELISA kit according to the manufacturer's instruction (Abcam). Serum concentrations and liver levels of hepcidin were determined using a hepcidin ELISA kit (Nanjing Jiancheng Bioengineering Institute) based on a competitive binding method. Tap water and liver samples were digested by Microwave Digestion System (EHD36 electrothermal hotblock digester; LabTech) according to the procedures described previously ${ }^{(20)}$. Fe concentrations in tap water and liver were measured by graphite furnace atomic absorption spectroscopy using a Graphite Atomic Absorption Spectrometer (Z-2000; Hitachi High-Technologies Corp.).

\section{Real-time PCR for MRNA quantification}

Total RNA was isolated from duodenal mucosa and liver samples using TRIzol reagent (Invitrogen). RNA samples $(2 \mu \mathrm{g})$ were treated with DNase and reverse transcribed to complementary DNA (cDNA) using random hexamer primers (Promega). A quantity of $2 \mu \mathrm{l}$ of diluted cDNA (1:25) was utilised in real-time PCR performed in Mx3000P (Stratagene). Peptidylprolyl isomerase A (PPIA) was chosen as a reference gene to normalise the mRNA abundance of target genes, because its mRNA abundance was not affected by maternal dietary treatment. Real-time PCR data were analysed by using the $2^{-\Delta \Delta C_{t}} \operatorname{method}^{(21)}$. The mRNA levels were expressed as the fold change relative to the mean 
Table 2. Nucleotide sequences of specific primers

\begin{tabular}{|c|c|c|c|}
\hline Target genes & Primer sequence $\left(5^{\prime}-3^{\prime}\right)$ & Product (bp) & GenBank no. \\
\hline Dcytb & $\begin{array}{l}\text { F: TCCACGCAGGGTTGAATAC } \\
\text { R: GCCCAAGGAAGCAGAAAGAC }\end{array}$ & 187 & NM_001128452.1 \\
\hline DMT1 & $\begin{array}{l}\text { F: TAGAAATAGCAGCAGTCCC } \\
\text { R: CGAAGTAACACCCTAGCAC }\end{array}$ & 101 & NM_001128440.1 \\
\hline Ferritin $H$ & $\begin{array}{l}\text { F: TCGCTGCGGTTTCCTG } \\
\text { R: TCCGAGTCCTGGTGGTAGTT }\end{array}$ & 229 & XM_005660803 \\
\hline Ferritin L & $\begin{array}{l}\text { F: CGAGGGTTCGGAGCGTCT } \\
\text { R: GCAGGTTGGTCAGGTGGTC }\end{array}$ & 278 & NM_001244131 \\
\hline FPN & $\begin{array}{l}\text { F: TGAATGCCACAATACGAAG } \\
\text { R: CCATCCCGAAATAAAGC }\end{array}$ & 116 & NM_014585.5 \\
\hline HP & $\begin{array}{l}\text { F: TGCCAGCCGCCCCTACTCT } \\
\text { R: CTTCAGGATGCCCTTTCG }\end{array}$ & 241 & XM_003135142 \\
\hline TF & $\begin{array}{l}\text { F: GTATCCGCAGAAAACACCG } \\
\text { R: AGGACAGGCACCAGACCAC }\end{array}$ & 119 & NM_001244653 \\
\hline TFR1 & $\begin{array}{l}\text { F: CAGTTGAACAGAATGGCACG } \\
\text { R: CAGACTCAGACCCATCTCCCT }\end{array}$ & 174 & NM_214001 \\
\hline TFR2 & $\begin{array}{l}\text { F: CCTCCCAGTCTCCCCTTAT } \\
\text { R: CCCCACGCATCCCTCT }\end{array}$ & 162 & XM_003124374 \\
\hline PPIA & $\begin{array}{l}\text { F: GACTGAGTGGTTGGATGG } \\
\text { R: TGATCTTCTTGCTGGTCTT }\end{array}$ & 116 & NM_214353.1 \\
\hline
\end{tabular}

Dcytb, duodenal cytochrome b; DMT1, divalent metal transporter 1; Ferritin $H$, ferritin heavy chain; Ferritin $L$, ferritin light chain; FPN, ferroportin; HP, hephaestin; TF, transferrin; TFR1, TF receptor 1; TFR2,TF receptor 2; PPIA, peptidylprolyl isomerase A.

value of the SP group. Primers for real-time PCR were synthesised by Generay Biotech Co., Ltd. and are presented in Table 2.

\section{Protein extraction and Western blot analysis}

Total protein was extracted from frozen duodenal mucosa and liver using lysis buffer (150 mm NaCl, 10 mm TRIS-HCl, 5 mm EDTA, $1 \%$ Triton X-100 and 0.1\% SDS). The protease inhibitor cocktail (Roche Applied Science) was added according to the manufacturer's instruction. The protein concentration was measured by a Pierce BCA Protein Assay Kit (Thermo Scientific). Western blot analysis of DMT1 (M10; Abnova), FPN (SC49668; Santa Cruz Biotechnology), ferritin heavy chain (Ferritin H) (ab81444; Abcam), TF (HPA001527; Sigma), Transferrin receptor 1 (TFR1) (10084-2-AP; Proteintech Group Inc.) and $\beta$-actin (ab8227; Abcam) was carried out according to the protocols provided by the primary antibody suppliers. The band density of target proteins was normalised with that of $\beta$-actin, and the content of target proteins is presented as fold change relative to the SP group.

\section{Statistical analysis}

Results are reported as mean values with their standard errors. All data were analysed using independent-samples $t$ test with SPSS 20.0 to examine differences between the two groups. Individual sows or piglets served as the experimental unit. A value of $P<0.05$ was regarded as statistically significant.

\section{Results}

Effect of maternal low-protein diet on growth performance of piglets

Maternal LP diet did not affect the birth weight, but significantly inhibited the early postnatal growth of offspring piglets (Table 3 ). Piglets in the LP group had lower body weight $(P=0.03)$ at weaning with decreased average daily gain (ADG, $P=0.01$ ) as
Table 3. Effect of maternal low-protein (LP) diet on growth performance of piglets (Mean values with their standard errors)

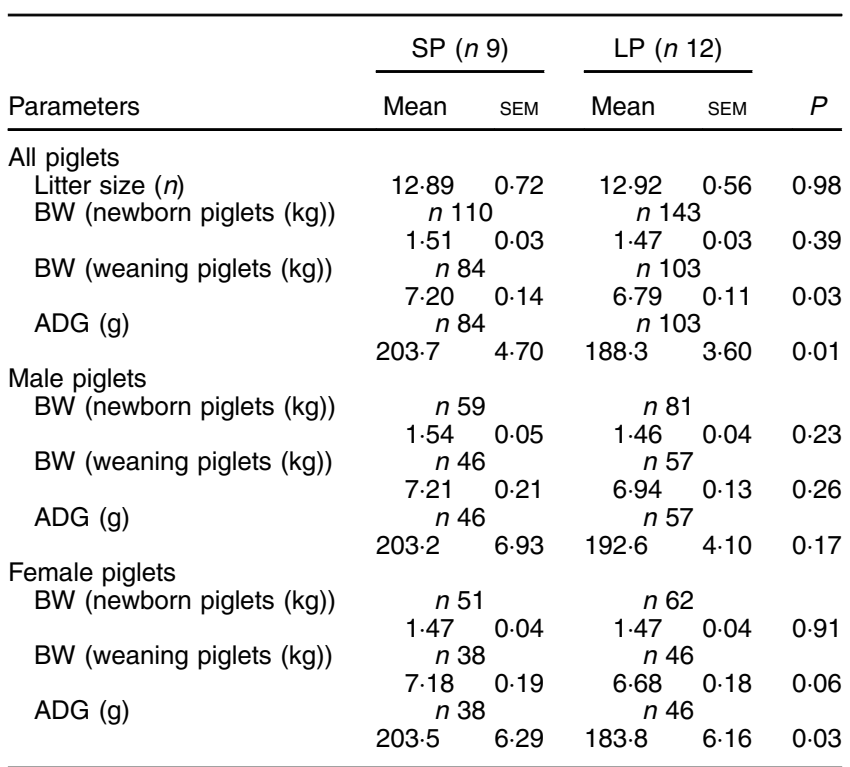

$\mathrm{SP}$, standard protein diet; $\mathrm{BW}$, body weight; $\mathrm{ADG}$, average daily gain.

compared with their counterparts in the SP group. When male and female piglets were separately analysed, the body weight did not differ markedly at birth and weaning regardless of sex, whereas female piglets in the LP group exhibited drastically decreased $(P=0.03)$ ADG.

\section{Effect of maternal low-protein diet on serum iron levels in sows and piglets}

No meaningful differences were observed in serum Fe levels of sows or newborn piglets between the SP and LP groups 
Table 4. Effect of maternal low-protein (LP) diet on serum iron levels in sows and piglets

(Mean values with their standard errors)

\begin{tabular}{|c|c|c|c|c|c|}
\hline \multirow[b]{2}{*}{ Parameters } & \multicolumn{2}{|c|}{ SP } & \multicolumn{2}{|c|}{ LP } & \multirow[b]{2}{*}{$P$} \\
\hline & Mean & SEM & Mean & SEM & \\
\hline \multicolumn{6}{|l|}{ Sow } \\
\hline \multirow[t]{2}{*}{$\mathrm{Fe}(\mu \mathrm{mol} / \mathrm{l})$} & \multicolumn{2}{|c|}{$n 6$} & \multicolumn{2}{|c|}{$n 6$} & \\
\hline & 56.49 & 5.53 & $45 \cdot 11$ & $2 \cdot 33$ & 0.09 \\
\hline \multicolumn{6}{|l|}{ Newborn piglets } \\
\hline \multirow[t]{2}{*}{ Fe (all piglets $(\mu \mathrm{mol} / \mathrm{l}))$} & \multicolumn{2}{|c|}{$n 16$} & \multicolumn{2}{|c|}{$n 14$} & \\
\hline & \multicolumn{2}{|c|}{$n 8$} & $\begin{array}{r}38.20 \\
n\end{array}$ & $4 \cdot 11$ & 0.74 \\
\hline Fe (male piglets $(\mu \mathrm{mol} / \mathrm{l}))$ & 44.56 & 3.60 & 35.47 & 6.07 & 0.23 \\
\hline \multirow[t]{2}{*}{ Fe (female piglets $(\mu \mathrm{mol} / \mathrm{l}))$} & \multicolumn{2}{|c|}{$n 8$} & \multicolumn{2}{|c|}{$n 7$} & \\
\hline & 35.37 & $5 \cdot 17$ & $40 \cdot 93$ & $5 \cdot 82$ & 0.49 \\
\hline \multicolumn{6}{|l|}{ Weaning piglets } \\
\hline \multirow[t]{2}{*}{ Fe (all piglets $(\mu \mathrm{mol} / \mathrm{l}))$} & \multicolumn{2}{|c|}{$n 16$} & \multicolumn{2}{|c|}{$n 16$} & \\
\hline & $46 \cdot 76$ & $2 \cdot 15$ & $35 \cdot 66$ & $3 \cdot 16$ & 0.01 \\
\hline \multirow[t]{2}{*}{$\mathrm{Fe}($ male piglets $(\mu \mathrm{mol} / \mathrm{l}))$} & \multicolumn{2}{|c|}{$n 8$} & \multicolumn{2}{|c|}{$n 8$} & \\
\hline & \multicolumn{2}{|c|}{$n 8$} & $\begin{array}{r}35.82 \\
n\end{array}$ & $5 \cdot 13$ & 0.03 \\
\hline Fe (female piglets $(\mu \mathrm{mol} / \mathrm{l}))$ & 43.40 & $3 \cdot 10$ & 35.49 & 4.05 & 0.14 \\
\hline
\end{tabular}

SP, standard protein diet.

Table 5. Effect of maternal low-protein (LP) diet on serum iron metabolism-related parameters in male weaning piglets (Mean values with their standard errors)

\begin{tabular}{lcccccc}
\hline & \multicolumn{2}{c}{ SP $(n 6)$} & & \multicolumn{2}{c}{ LP $(n$ 6) } & \\
\cline { 2 - 3 } Parameters & Mean & SEM & & Mean & SEM & $P$ \\
\hline Hepcidin $(\mathrm{ng} / \mathrm{ml})$ & 328.26 & 18.38 & & 335.22 & 7.14 & 0.74 \\
Ferritin $(\mathrm{ng} / \mathrm{ml})$ & 67.07 & 4.01 & & 59.60 & 1.59 & 0.08 \\
Transferrin $(\mathrm{mg} / \mathrm{l})$ & 144 & 5.12 & & 263 & 5.00 & 0.01 \\
\hline
\end{tabular}

SP, standard protein diet.

(Table 4). However, serum Fe concentration was significantly lower in weaning piglets $(P=0 \cdot 01)$, especially for males ( $P=0.03)$ of the LP group. No significant $(P=0 \cdot 14)$ reduction in serum Fe level was observed in protein-restricted female weaning piglets

\section{Effect of maternal low-protein diet on serum iron metabolism-related parameters in male weaning piglets}

Male piglets born to LP sows had a higher serum level of TF $(P=0 \cdot 01)$ compared with those born to SP sows (Table 5). Maternal LP diet caused a numerical decline of serum ferritin concentrations $(P=0.08)$ in male weaned piglets. Maternal LP diet did not affect serum hepcidin level $(P=0.74)$ in male piglets at weaning.

Effect of maternal low-protein diet on expression of iron metabolism-related genes and proteins in the duodenum of male weaning piglets

Six genes involved in intestinal Fe absorption, storage and transport, including duodenal cytochrome b (Dcytb), DMT1, Ferritin H, Ferritin $L, F P N$ and haphaestin, were quantified at the

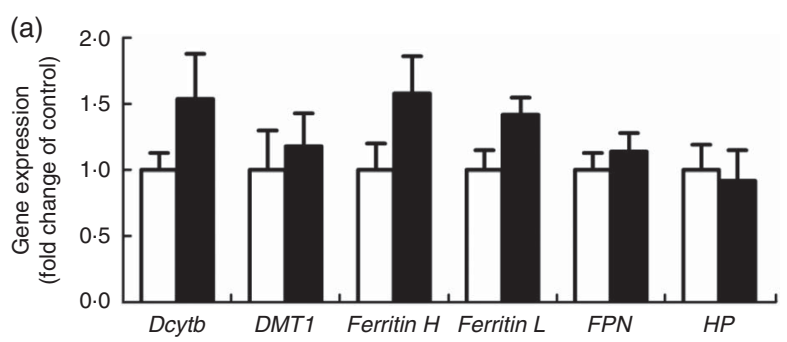

(b)
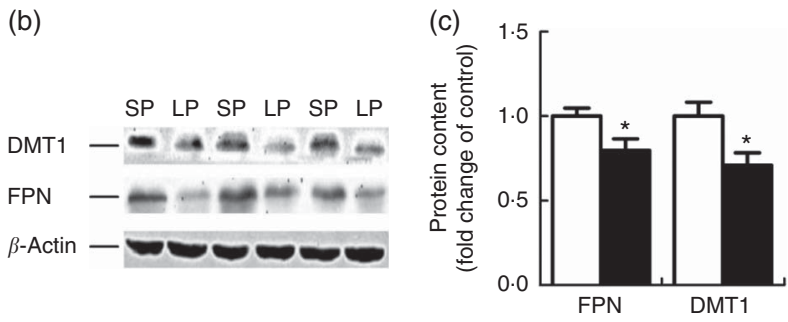

Fig. 1. Effect of maternal low-protein (LP) diet on iron metabolism-related gene (a) and protein (b, c) expression in duodenum of male weaning piglets. Values are means, with their standard errors represented by vertical bars. $\square$, Standard protein (SP); 1 , LP; Dcytb, duodenal cytochrome b; DMT1, divalent metal transporter 1; Ferritin $\mathrm{H}$, ferritin heavy chain; Ferritin $L$, ferritin light chain; FPN, ferroportin; $H P$, hephaestin. ${ }^{*} P<0.05$, compared with control $(n 6)$.

mRNA level in the duodenum of male weaning piglets and none of the genes exhibited a significant difference between the groups (Fig. 1(a)). However, the protein content of DMT1 and FPN was significantly down-regulated $(P<0.05)$ in the duodenum of male weaning piglets in the LP group (Fig. 1(b)).

\section{Effect of maternal low-protein diet on iron content, hepcidin levels, iron metabolism-related gene and protein expression in the liver of male weaning piglets}

Hepatic Fe content (Fig. 2(a)) did not differ between the LP and SP groups. Liver hepcidin levels tended to be higher $(P=0.09)$ (Fig. 2(b)) in the LP piglets. TF and TFR1 were significantly down-regulated $(P<0.01$ or 0.05$)$ at the mRNA levels within the liver of male weaning piglets of the LP group (Fig. 2(c)); yet, no alterations were detected for hepatic ferritin, TFR1 and TF protein expression (Fig. 2(d)).

\section{Discussion}

Maternal malnutrition during gestation and/or lactation is suggested to induce a programming of offspring growth and development in later life ${ }^{(22,23)}$. Some data indicate that offspring born to dams fed a restricted protein diet throughout gestation were thinner at birth in pigs ${ }^{(24-27)}$ or rodents ${ }^{(28-30)}$. In the current study, feeding a diet containing LP (7.5\%) to gilts throughout gestation did not affect the birth weight of piglets, different from what was reported in previous studies. Reduced offspring birth weight caused by maternal protein restriction was presumably associated with the protein concentrations in maternal diets ${ }^{(24-27)}$ and feeding patterns (feed restriction or free feeding) ${ }^{(28-30)}$. Maternal protein restriction ( $0.5 \%$ ) throughout pregnancy resulted in lower birth weight among piglets compared with normal 
(a)

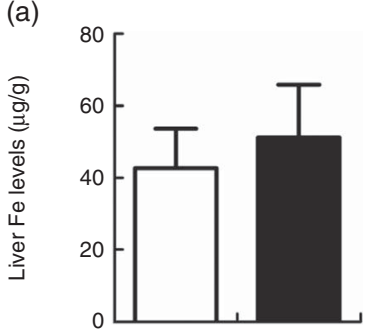

(b)
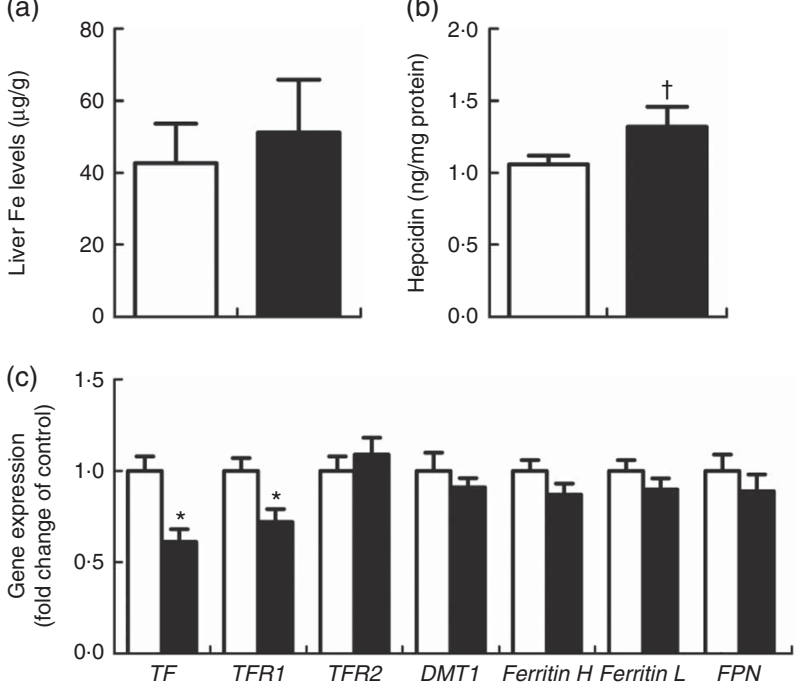

(d) (e)

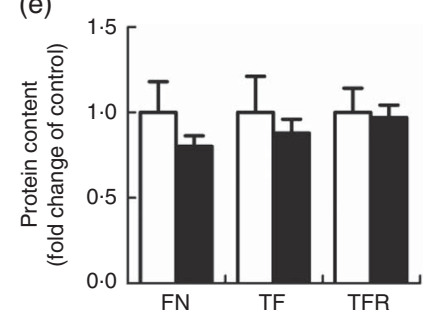

Fig. 2. Effect of maternal low-protein (LP) diet on iron content (a), hepcidin levels (b), iron metabolism-related gene (c) and protein (d, e) expression in liver of male weaning piglets. Values are means, with their standard errors represented by vertical bars. $\square$, Standard protein (SP); $\square$, LP; TF, transferrin; TFR, TF receptor; $D M T 1$, divalent metal transporter 1; Ferritin $H$, ferritin heavy chain; Ferritin $L$, ferritin light chain; $F P N$, ferroportin; $F N$, ferritin. $\dagger P=0.09$, * $P<0.05$, compared with control $(n 6)$.

protein $(13 \%)$ level ${ }^{(24,25)}$. Offspring birth weight was greatly reduced when gilts were fed a certain amount of LP (6.5 or $6.1 v$. $12 \cdot 1 \%$ protein) diet/d during pregnancy ${ }^{(26,27)}$. Offspring birth weights of dams fed ad libitum an LP diet ( 8 or $10 \%$ protein) were markedly lighter compared with those of progeny of mice fed a $20 \%$ protein diet ${ }^{(28-30)}$. Maternal LP diet during gestation and lactation leads to lower body weight and ADG in weaning piglets, especially in female piglets. This study confirms former reports employing rodent models ${ }^{(30-32)}$. It is reported that maternal LP diet dramatically altered milk composition, resulting in a severe reduction in the concentrations of essential amino acids, non-essential amino acids, total fatty acids, and lipid content in the milk ${ }^{(32)}$. The lowered milk quality induced by the maternal LP diet could be responsible for postnatal offspring growth ${ }^{(32)}$.

Dietary protein restriction during pregnancy or/and lactation induces a reduction in serum Fe concentrations in dams ${ }^{(15)}$ and in the offspring of rats ${ }^{(19)}$. In the current study, lowered serum Fe level and enhanced TF concentration indicate that maternal protein restriction affects the Fe metabolism in male weaned piglets $^{(33,34)}$. Serum TF levels increase with Fe reduction and reduce during Fe overload; thus, an enhanced serum TF level is used as a marker of $\mathrm{Fe}$ reduction ${ }^{(35)}$. It is evident that certain amino acids including lysine, methionine, cystine, histidine,

serine, proline, glutamine and so on ${ }^{(16,36)}$ are used as enhancers for Fe absorption in the intestine. A restricted protein diet during lactation decreases the essential amino acids (e.g. histidine, proline, lysine, methionine, valine and so on) and non-essential amino acids (e.g. glutamine, glycine, serine, tyrosine and so on) in the milk of sows ${ }^{(37)}$. It is suggested that maternal protein restriction might disturb $\mathrm{Fe}$ transport via reduced Fe-enhancer concentrations of amino acids.

In addition, our results showed that maternal protein restriction throughout gestation and lactation reduced DMT1 and FPN protein expression but not DMT1 and FPN mRNA abundance in the duodenum of male weaned piglets. Fe is taken up mainly in the duodenum of pigs ${ }^{(38,39)}$. DMT1, encoded by the SLC11A2 gene, is in charge of the transport of $\mathrm{Fe}^{2+}$ and other divalent metals from the lumen into the duodenal cells ${ }^{(40,41)}$. FPN, encoded by the SLC4OA1 gene, is the only known Fe exporter in mammalian cells ${ }^{(6,42)}$. The reduced protein expression of Fe influx transporter DMT1 and efflux transporter FPN inhibits intestinal Fe transport and decreases $\mathrm{Fe}$ levels in the circulation ${ }^{(43-45)}$. Unchanged transcript expressions and decreased protein expression of DMT1 and FPN suggest that DMT1 and FPN are regulated at the post-transcriptional level or translational level ${ }^{(46,47)}$. In all, twentytwo microRNA targeting DMT1 or FPN were examined, but there were no noteworthy differences between the two groups (data not provided). Hepcidin, encoded by the HAMP gene, is a key regulator of $\mathrm{Fe}$ entry into the circulation by binding and down-regulating the DMT1 of enterocytes ${ }^{(8,48)}$ and FPN of the enterocytes, macrophages and hepatocytes in mammals ${ }^{(9,49)}$. However, there is no difference in serum hepcidin levels between the two groups. The mechanism of down-regulation of DMT1 and FPN in the duodenum of male weaning piglets needs further study.

Maternal protein restriction enhanced hepatic hepcidin levels, decreased liver TF and TFR mRNA levels, but did not affect the liver Fe concentrations, ferritin, TF and TFR protein abundance in male weaned piglets. TF is an Fe-binding blood plasma glycoprotein that delivers $\mathrm{Fe}$ to tissue cells via a receptor-mediated endocytotic process or internalisation ${ }^{(34,50)}$. Almost all $\mathrm{Fe}$ in the circulation is transported by plasma $\mathrm{TF}^{(51)}$. Plasma TF loaded with $\mathrm{Fe}^{3+}$ encounters and binds to its receptors on the cell surface and being endocytosed in the liver. Furthermore, it is reported that intramuscular administration of iron dextran induces hepatic Fe accumulation in piglets ${ }^{(39,52)}$. Hepatic Fe concentrations persist at $60-100 \mathrm{mg} / \mathrm{kg}$ at day 20 and $25-40 \mathrm{mg} / \mathrm{kg}$ at day 30 when piglets are injected with $100 \mathrm{mg}$ of iron dextran at days $1-3^{(53)}$. Rising levels of serum TF and injection of iron dextran could play a role in unchanged liver Fe deposition in male weaning piglets of the LP group.

In conclusion, our results indicate that the maternal protein restriction during gestation and lactation decreases female offspring growth performance at weaning. Maternal protein restriction throughout pregnancy and lactation significantly suppresses the duodenal expression of Fe transporters (DMT1 and FPN) and reduces serum Fe level in male weaning piglets.

\section{Acknowledgements}

The present study was supported by the National Basic Research Program of China (2012CB124703), the National Natural Science 
Foundation of China (31302053), the Fundamental Research Funds for the Central Universities (KJQN201404), the Innovation Project of Jiangsu Province Postgraduate Education (2013CXIX13_292), the Priority Academic Program Development of Jiangsu Higher Education Institutions and the Jiangsu Collaborative Innovation Center of Meat Production and Processing, Quality and Safety Control.

R. Z. and W. M. conceived the project. J. L. performed most experiments. S. J. analysed the data. D. C. assisted the western blot assay. S. P. and Y. J. conducted the animal experiment. W. M. wrote the manuscript. All authors reviewed the results and approved the final version of the manuscript.

The authors declare that there are no conflicts of interest.

\section{References}

1. Victor I \& Mary I (2012) Iron nutrition and anaemia in piglets: a review. J Vet Adv 2, 261-265.

2. Perri AM, Friendship RM, Harding JCS, et al. (2015) An investigation of iron deficiency and anemia in piglets and the effect of iron status at weaning on post-weaning performance. J Swine Health Prod 24, 10-20.

3. Loh $\mathrm{T}$ Jr, Leong $\mathrm{K}$, Too $\mathrm{H}$, et al. (2001) The effects of iron supplementation in preweaning piglets. Malays $J$ Nutr $\mathbf{7}$, 41-49.

4. Martini LA, Tchack L \& Wood RJ (2002) Iron treatment downregulates DMT1 and IREG1 mRNA expression in Caco-2 cells. J Nutr 132, 693-696.

5. Foot NJ, Dalton HE, Shearwin-Whyatt LM, et al. (2008) Regulation of the divalent metal ion transporter DMT1 and iron homeostasis by a ubiquitin-dependent mechanism involving Ndfips and WWP2. Blood 112, 4268-4275.

6. Donovan A, Lima CA, Pinkus JL, et al. (2005) The iron exporter ferroportin/Slc40a1 is essential for iron homeostasis. Cell Metab 1, 191-200.

7. Theurl I, Aigner E, Theurl M, et al. (2009) Regulation of iron homeostasis in anemia of chronic disease and iron deficiency anemia: diagnostic and therapeutic implications. Blood 113, 5277-5286.

8. Brasse-Lagnel C, Karim Z, Letteron P, et al. (2011) Intestinal DMT1 cotransporter is down-regulated by hepcidin via proteasome internalization and degradation. Gastroenterology 140, 1261-1271.

9. Qiao B, Sugianto P, Fung E, et al. (2012) Hepcidin-induced endocytosis of ferroportin is dependent on ferroportin ubiquitination. Cell Metab 15, 918-924.

10. Zijp IM, Korver O \& Tijburg LB (2000) Effect of tea and other dietary factors on iron absorption. Crit Rev Food Sci Nutr $\mathbf{4 0}$, 371-398.

11. Hurrell R \& Egli I (2010) Iron bioavailability and dietary reference values. Am J Clin Nutr 91, 1461S-1467S.

12. Xin W, Xugang S, Xie C, et al. (2013) The acute and chronic effects of monosodium L-glutamate on serum iron and total iron-binding capacity in the jugular artery and vein of pigs. Biol Trace Elem Res 153, 191-195.

13. Klavins JV, Kinney TD \& Kaufman N (1961) The influence of dietary protein on iron absorption. Br J Exp Pathol 43, 172-180.

14. Spruill DG, Hays VW \& Cromwell GL (1971) Effects of dietary protein and iron on reproduction and iron-related blood constituents in swine. J Anim Sci 33, 376-384.

15. Thomas CE, Gaffney-Stomberg E, Sun BH, et al. (2013) Increasing dietary protein acutely augments intestinal iron transporter expression and significantly increases iron absorption in rats. FASEB J 27, 2476-2483.

16. Kone DJ, Kinney TD, Kaufman N, et al. (1963) The influence of amino acids on iron absorption. Blood 21, 546.

17. Menendez-Castro C, Fahlbusch F, Cordasic N, et al. (2011) Early and late postnatal myocardial and vascular changes in a protein restriction rat model of intrauterine growth restriction. PLOS ONE 6, e20369.

18. Metges CC, Görs S, Lang IS, et al. (2014) Low and high dietary protein:carbohydrate ratios during pregnancy affect maternofetal glucose metabolism in pigs. J Nutr 144, 155-163.

19. Enwonwu CO, Monsen ER \& Jacobson K (1972) Absorption of iron in protein-calorie deficient rats and immediate effects of re-feeding an adequate protein diet. Am J Dig Dis 17, 959-968.

20. Ma W, Gu Y, Lu J, et al. (2014) Effects of chromium propionate on egg production, egg quality, plasma biochemical parameters, and egg chromium deposition in late-phase laying hens. Biol Trace Elem Res 157, 113-119.

21. Livak KJ \& Schmittgen TD (2001) Analysis of relative gene expression data using realtime quantitative PCR and the 2(-Delta delta C(T)) method. Methods 25, 402-408.

22. Eriksson JG (2010) Early programming of later health and disease: factors acting during prenatal life might have lifelong consequences. Diabetes 59, 2349-2350.

23. Fernandez-Twinn DS \& Ozanne SE (2010) Early life nutrition and metabolic programming. Ann N Y Acad Sci 1212, 78-96.

24. Davis TA, Fiorotto ML, Burrin DG, et al. (1997) Intrauterine growth restriction does not alter response of protein synthesis to feeding in newborn pigs. Am J Physiol 272, E877-E884.

25. Pond WG, Maurer RR, Mersmann HJ, et al. (1992) Response of fetal and newborn piglets to maternal protein restriction during early or late pregnancy. Growth Dev Aging 56, 115-127.

26. Rehfeldt C, Lang IS, Görs S, et al. (2011) Limited and excess dietary protein during gestation affects growth and compositional traits in gilts and impairs offspring fetal growth. J Anim Sci 89, 329-341.

27. Shang Y, Jia Y, Sun Q, et al. (2015) Sexually dimorphic effects of maternal dietary protein restriction on fetal growth and placental expression of $11 \beta$-HSD2 in the pig. Anim Reprod Sc $i$ 160, 40-48.

28. Zambrano E, Bautista CJ, Deás M, et al. (2006) A low maternal protein diet during pregnancy and lactation has sex- and window of exposure-specific effects on offspring growth and food intake, glucose metabolism and serum leptin in the rat. J Physiol 571, 221-230.

29. Chen JH, Martin-Gronert MS, Tarry-Adkins J, et al. (2009) Maternal protein restriction affects postnatal growth and the expression of key proteins involved in lifespan regulation in mice. PLOS ONE $\mathbf{4}$, e4950.

30. Han R, Li A, Li L, et al. (2012) Maternal low-protein diet up-regulates the neuropeptide $\mathrm{Y}$ system in visceral fat and leads to abdominal obesity and glucose intolerance in a sexand time-specific manner. FASEB J 26, 3528-3536.

31. Zambrano E, Martínez-Samayoa PM, Bautista CJ, et al. (2005) Sex differences in transgenerational alterations of growth and metabolism in progeny (F2) of female offspring (F1) of rats fed a low protein diet during pregnancy and lactation. $J$ Physiol 566, 225-236.

32. Peixoto-Silva N, Frantz ED, Mandarim-de-Lacerda CA, et al. (2011) Maternal protein restriction in mice causes adverse metabolic and hypothalamic effects in the F1 and F2 generations. Br J Nutr 106, 1364-1373.

33. Wang W, Knovich MA, Coffman LG, et al. (2010) Serum ferritin: past, present and future. Biochim Biophys Acta 1800, $760-769$. 
34. Macedo MF \& de Sousa M (2008) Transferrin and the transferrin receptor: of magic bullets and other concerns. Inflamm Allergy Drug Targets 7, 41-52.

35. Gkouvatsos K, Papanikolaou G \& Pantopoulos K (2012) Regulation of iron transport and the role of transferrin. Biochim Biophys Acta 1820, 188-202.

36. Martin Agnoux A, Antignac JP, Boquien CY, et al. (2015) Perinatal protein restriction affects milk free amino acid and fatty acid profile in lactating rats: potential role on pup growth and metabolic status. J Nutr Biochem 26, 784-795.

37. Van Campen D (1973) Enhancement of iron absorption from ligated segments of rat intestine by histidine, cysteine, and lysine: effects of removing ionizing groups and of stereoisomerism. J Nutr 103, 139-142.

38. Blachier F, Vaugelade P, Robert V, et al. (2007) Comparative capacities of the pig colon and duodenum for luminal iron absorption. Can J Physiol Pharmacol 85, 185-192.

39. Lipinski P, Starzyński RR, Canonne-Hergaux F, et al. (2010) Benefits and risks of iron supplementation in anemic neonatal pigs. Am J Pathol 177, 1233-1243.

40. Mims MP \& Prchal JT (2005) Divalent metal transporter 1. Hematology 10, 339-345.

41. Jiang L, Garrick MD, Garrick LM, et al. (2013) Divalent metal transporter 1 (Dmt1) mediates copper transport in the duodenum of iron-deficient rats and when overexpressed in iron-deprived HEK-293 cells. J Nutr 143, 1927-1933.

42. Donovan A, Brownlie A, Zhou Y, et al. (2000) Positional cloning of zebrafish ferroportin1 identifies a conserved vertebrate iron exporter. Nature $\mathbf{4 0 3}, 776-781$.

43. Griffiths WJ, Sly WS \& Cox TM (2001) Intestinal iron uptake determined by divalent metal transporter is enhanced in HFE- deficient mice with hemochromatosis. Gastroenterology $\mathbf{1 2 0}$ 1420-1429.

44. Chen J, Shen H, Chen C, et al. (2009) The effect of psychological stress on iron absorption in rats. BMC Gastroenterol 9, 83.

45. Ward DM \& Kaplan J (2012) Ferroportin-mediated iron transport: expression and regulation. Biochim Biophys Acta 1823, 1426-1433.

46. Galy B, Ferring-Appel D, Becker C, et al. (2013) Iron regulatory proteins control a mucosal block to intestinal iron absorption. Cell Rep 3, 844-857.

47. Meister G (2007) miRNAs get an early start on translational silencing. Cell 131, 25-28.

48. Mena NP, Esparza A, Tapia V, et al. (2008) Hepcidin inhibits apical iron uptake in intestinal cells. Am J Physiol Gastrointest Liver Physiol 294, G192-G198.

49. Nemeth E, Tuttle MS, Powelson J, et al. (2004) Hepcidin regulates cellular iron efflux by binding to ferroportin and inducing its internalization. Science 306, 2090-2093.

50. Leverence R, Mason AB \& Kaltashov IA (2010) Noncanonical interactions between serum transferrin and transferrin receptor evaluated with electrospray ionization mass spectrometry. Proc Natl Acad Sci U S A 107, 8123-8128.

51. Ponka P, Beaumont C \& Richardson DR (1998) Function and regulation of transferrin and ferritin. Semin Hematol 35, 35-54.

52. Starzyński RR, Laarakkers CM, Tjalsma H, et al. (2013) Iron supplementation in suckling piglets: how to correct iron deficiency anemia without affecting plasma hepcidin levels. PLOS ONE 8, e64022.

53. Ness A, Engle M \& Thompson B (2010) Iron toxicity in piglets. In Proceedings of the American Association of Swine Veterinarians Conference, Omaha, NE, 2010, pp. 233-235. 